\title{
Mechanical and Durability Performance of Roller-Compacted Concrete with Fly Ash for Dam Applications
}

\author{
Chan-Gi Park ${ }^{1)}$, Jong-Whan Yoon ${ }^{2)}$, Wan-Young Kim ${ }^{3)}$, and Jong-Pil Won ${ }^{4) *}$
}

(Received May 7, 2007, Accepted December 18, 2007)

\begin{abstract}
This study investigated the mechanical and durability performance of roller-compacted concrete (RCC) with fly ash for dam applications. A test program studied the effects on the properties of fresh and hardened RCC with fly ash replacement ratio, as well as the long-term durability of the resulting mixture. Fly ash replaced 20,30, 40, and $50 \%$ by mass of the cement. Laboratory tests of the compressive strength, splitting tensile strength, shear strength, chloride ion permeability, abrasion, and drying shrinkage were conducted. The test results demonstrated that $30 \%$ fly ash replacement is an optimum level, and that this mixture has excellent mechanical and durability properties.
\end{abstract}

Keywords: Dam, durability, fly ash, roller-compacted concrete (RCC)

\section{Introduction}

Roller-compacted concrete (RCC) dams combine the advantages of earth-fill and concrete dams in construction. They have gained acceptance worldwide in a relatively short time owing to their low cost, which is derived in part from their rapid construction method. ${ }^{1,7,10,13}$ RCC has recently emerged as an economically attractive material for dam construction, replacing the use of conventional concrete and even challenging the economics of earth-fill and rock-fill embankment dams. ${ }^{2,5,69} \mathrm{RCC}$ does not slump, and the unit amount of cement in the mixture is very low. Therefore, the amounts of mass change, drying shrinkage, and creep are low. RCC also has the advantage of lower heat of hydration during the construction of large sections, such as are found in dams. ${ }^{1,8,12,14}$ Many studies of the methods of construction and mix-proportions of RCC dams have been erformed. ${ }^{4,8,13}$ The US Army Corps of Engineers began a concerted effort to develop RCC for use in building concrete dams in the early 1970s. ${ }^{6}$ The Corps built field test sections in Jackson, Mississippi, in 1972, and at the site of the Lost Creek Dam in Oregon in $1973 .{ }^{6}$ The field tests confirmed the basic construction method and provided information on the material properties and the strength of the bonds between successive layers of RCC. Based on the data developed in these tests, a mix and a construction method were

\footnotetext{
${ }^{1)}$ KCI member, Dept. of Rural Construction Engineering, Kongju National University, Yesan 343-702, Korea.

${ }^{2} \mathrm{KCI}$ member, Dept. of Civil and Environmental System Engineering, Konkuk University, Seoul 143-701, Korea.

${ }^{3)} \mathrm{KCI}$ member, Dept. of Dam Engineering Research Center, Korea Institute of Water and Environment, Daejeon 305-703, Korea

${ }^{4)} \mathrm{KCI}$ member, Dept. of Civil and Environmental System Engineering, Konkuk University, Seoul 143-701, Korea.E-mail: jpwon@konkuk.ac.kr Copyright (c) 2007, Korea Concrete Institute. All rights reserved, including the making of copies without the written permission of the copyright proprietors.
}

proposed. The mix and design method of the US Army Corps of Engineers was directly applied to the mix for a RCC dam. In Japan, because of the seismic, hydrologic, and topographic problems associated with most dam sites in the country, researchers have taken a more conservative approach to RCC mix proportions. Their aim is for a product with the same quality and appearance as that of conventionally placed, mass concrete gravity dams.

Various studies and experiments have led to a RCC method. Obtaining the mix for Japan required repeated experiments. ${ }^{8,13}$ This method obtained good quality concrete but required a long time. Although many studies have evaluated mix proportions and construction methods, few have analyzed the durability of RCC, which is very important. The various factors that can reduce the long-term performance of a RCC dam include abrasion, the shear strength and permeability of the construction joints. This study examined these properties so as to promote the practical application of fly ash in RCC construction. Therefore, the properties of RCC using increasing amounts of fly ash were evaluated.

\section{Target properties and materials}

\subsection{Target properties}

Target properties were determined based on the mix proportions of the Zugawa and Damagawa RCC dams in Japan. ${ }^{8,13}$ The target properties are shown in Table 1.

\subsection{Materials}

ASTM Type II Portland cement was used. The chemical composition of the cement is shown in Table 2. The fine and coarse aggregates were equivalent to rock. Crushed coarse aggregate with a maximum size of $80 \mathrm{~mm}$ and crushed fine aggregate with a specific gravity of 2.61 were used. The grade distributions of the coarse and fine aggregates are listed in Fig. 1. Fly ash was refined to satisfy the requirements of ASTM C 618. 
Table 1 Target properties of RCC.

\begin{tabular}{c|c|c|c|c}
\hline $\mathrm{F}_{\mathrm{ck}}(\mathrm{MPa})$ & $\mathrm{G}_{\max }(\mathrm{mm})$ & Slump $(\mathrm{mm})$ & $\mathrm{Vc}(\mathrm{sec})$ & Air (\%) \\
\hline \hline 11.77 & 80 & 0 & $20 \pm 10$ & $1.5 \pm 11$ \\
\hline
\end{tabular}

Table 2 Chemical composition of type II portland cement.

\begin{tabular}{c|c|c|c|c|c|c|c|c}
\hline $\mathrm{SiO}_{2}$ & $\mathrm{Al}_{2} \mathrm{O}_{3}$ & $\mathrm{Fe}_{2} \mathrm{O}_{3}$ & $\mathrm{CaO}$ & $\mathrm{MgO}$ & $\mathrm{Na}_{2} \mathrm{O}$ & $\mathrm{K} 2 \mathrm{O}$ & $\mathrm{SO}_{3}$ & Lg.loss \\
\hline \hline 23.3 & 3.9 & 3.6 & 62.4 & 2.9 & 0.11 & 0.82 & 1.9 & 1.0 \\
\hline
\end{tabular}

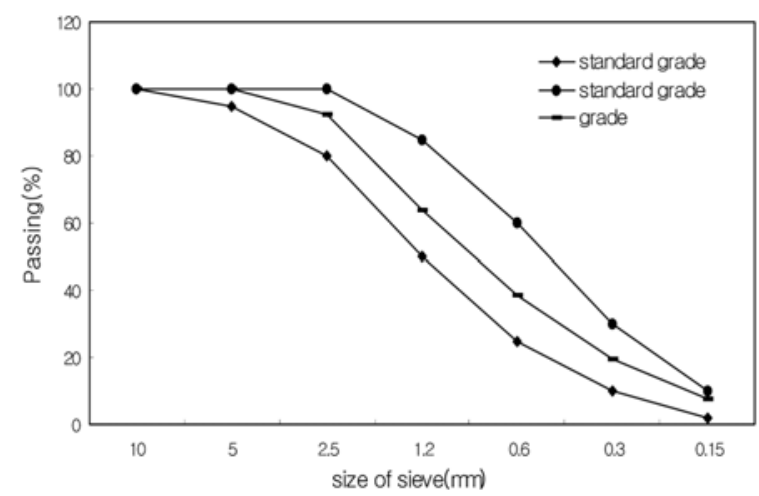

Fig. 1 Grade distributions of fine aggregate.

\subsection{Mix proportion}

In the development of mix proportions for the RCC mixture, there are basic guidelines that can be applied to optimize each of the materials. The mix proportions were based on the mix of the US Army Corps of Engineers and on those in Japan. ${ }^{8,13}$ The mix proportions were determined based on an $11.77 \mathrm{MPa}$ compressive strength at 91 days of age. The target slump of the fresh concrete was $0 \mathrm{~mm}$, the air content was $1 \pm 0.5 \%$, and the modified Vebe time was $20 \pm 10 \mathrm{~s}$. To determine the initial value in proportioning the RCC mixture the appropriate US Army Corps of Engineers' method was used, and the corresponding Japanese method was then applied to determine the exact proportions. The basic mix proportions were determined for unit amount of water $(95 \mathrm{~kg} /$ $\mathrm{m}^{3}$ ), unit amount of cement $\left(115 \mathrm{~kg} / \mathrm{m}^{3}\right)$, and S/a (35\%). The fly ash replacement by cement weight was evaluated based on the durability of the RCC mixture. The mix proportions are given in Table 3.

\section{Test method}

\subsection{Modified Vebe time and air content}

The Vebe test is a standard method of measuring the workability of stiff mixes, but it is not suitable for concrete mixes with the very low workability that is required for a compaction roller. A modified Vebe test was developed for testing RCC that had a similarly low workability to that required for roller compaction. ${ }^{3}$ The test is conducted with a weight placed on the plastic disc to speed up the collapse of the cone. Also, air content tests are conducted to evaluate the variation of the air content in accordance with ASTM C 231.

\subsection{Compressive strength}

The compressive strength tests followed the procedure of ASTM C 39. The load was applied according to this standard with an average loading rate of $116.7 \mathrm{kN} / \mathrm{min}$. and the failure load was recorded. The test involved the use of $300 \mathrm{~mm}$ long specimens that were $150 \mathrm{~mm}$ in diameter. The samples were tested at 7, 28, and 91 days of age. After mixing, cylinder specimens were produced according to ASTM C 1176 after coarse aggregate greater than $40 \mathrm{~mm}$ had been removed.

\subsection{Splitting tensile strength}

Splitting tensile tests were conducted in accordance with ASTM C 496. The cylindrical specimens were placed on their sides in an aligning jig similar to the one detailed in ASTM C 496. The specimens were tested at 7, 28, and 91 days of age.

\subsection{Shear strength}

Shear strength is one of the most important concrete properties of RCC dams. Specially, lift joint shear strength is generally the critical design value. RCC shear strength for lift joints can be lower than that of conventionally placed mass concrete. In this study, shear strength tests were carried out according to CRD C 90. Test specimens $150 \times 300 \mathrm{~mm}$ in size were initially cured for 1 day and then cured in water at $23 \pm 2^{\circ} \mathrm{C}$ for 91 days. The test was performed at 7,28 , and 91 days of age. The test equipment is shown in Fig. 2.

\subsection{Chloride ion permeability}

The chloride ion penetration tests were conducted in accordance with ASTMC 1202-94. The dimensions of the test specimens were $150 \times 50 \mathrm{~mm}$. The specimens were tested at 7,28 , and 91 days of age.

\subsection{Abrasion}

Abrasion tests were performed to evaluate the surface resistance of the RCC concrete. The tests were conducted according to ASTM C 944. Concrete specimens measuring $150 \times 60 \mathrm{~mm}$ were cast. The specimens were tested at 7, 28, and 91 days of age.

Table 3 Mix proportions of RCC.

\begin{tabular}{|c|c|c|c|c|c|c|c|c|c|c|c|}
\hline $\begin{array}{l}\text { Type of } \\
\text { mixture }\end{array}$ & $\begin{array}{l}\mathrm{G}_{\max } \\
(\mathrm{mm})\end{array}$ & $\begin{array}{c}\mathrm{Vc} \\
(\mathrm{sec})\end{array}$ & $\begin{array}{l}\text { Air } \\
(\%)\end{array}$ & $\mathrm{w} / \mathrm{c}$ & $\begin{array}{l}\text { S/a } \\
(\%)\end{array}$ & $\begin{array}{c}\mathrm{W} \\
\left(\mathrm{kg} / \mathrm{m}^{3}\right)\end{array}$ & $\begin{array}{c}\mathrm{C} \\
\left(\mathrm{kg} / \mathrm{m}^{3}\right)\end{array}$ & $\begin{array}{c}\mathrm{S} \\
\left(\mathrm{kg} / \mathrm{m}^{3}\right)\end{array}$ & $\begin{array}{c}\mathrm{G} \\
\left(\mathrm{kg} / \mathrm{m}^{3}\right)\end{array}$ & $\begin{array}{l}\text { Fly ash } \\
\left(\mathrm{kg} / \mathrm{m}^{3}\right)\end{array}$ & $\begin{array}{c}\mathrm{SP} \\
\left(\mathrm{kg} / \mathrm{m}^{3}\right)\end{array}$ \\
\hline FA0 & \multirow{5}{*}{80} & \multirow{5}{*}{$20 \pm 10$} & \multirow{5}{*}{$1.5 \pm 1$} & \multirow{5}{*}{0.79} & \multirow{5}{*}{34} & \multirow{5}{*}{92} & 117 & \multirow{5}{*}{765} & \multirow{5}{*}{1468} & 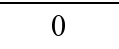 & \multirow{5}{*}{0.33} \\
\hline FA20 & & & & & & & 93.6 & & & 23.4 & \\
\hline FA30 & & & & & & & 81.9 & & & 35.1 & \\
\hline FA40 & & & & & & & 70.2 & & & 46.8 & \\
\hline FA50 & & & & & & & 58.5 & & & 58.5 & \\
\hline
\end{tabular}




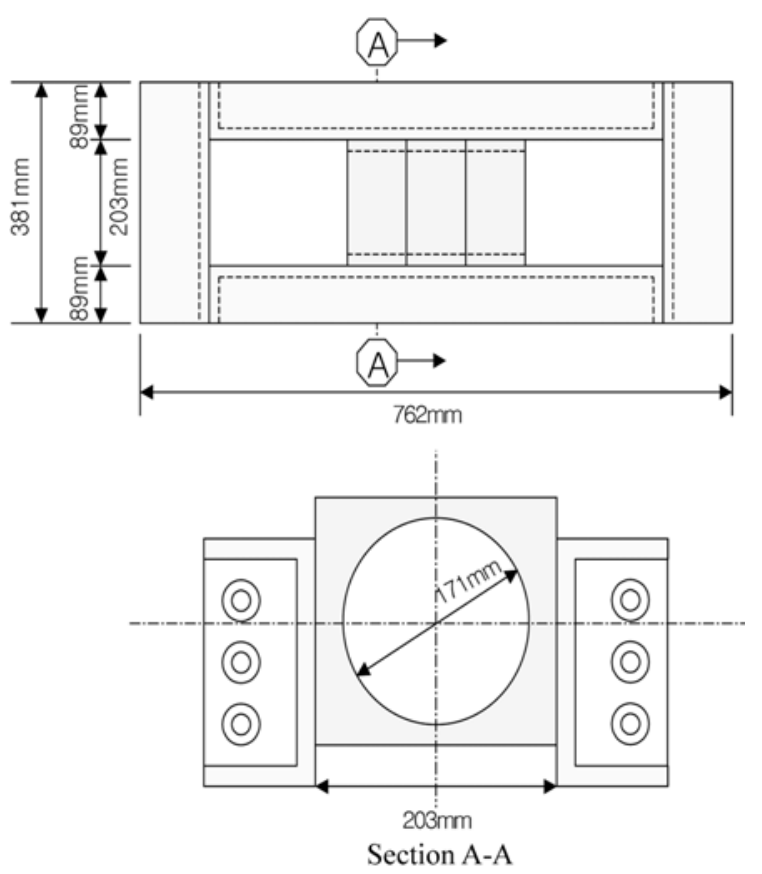

Fig. 2 Schematic of composition of shear test frame.

\subsection{Drying shrinkage}

The drying shrinkage of a RCC mixture is the volume reduction of the cement resulting from its hydration shrinkage after it starts to set. These tests were conducted in accordance with the JCI procedure. ${ }^{11}$ They were performed because the RCC mixture was applied to a large section. The drying shrinkage was measured over 28 days at $60 \%$ relative humidity and $23^{\circ} \mathrm{C}$. Figure 3 shows the drying shrinkage test apparatus setup.

\section{Results and discussions}

\subsection{Modified Vebe time and air content}

The results of the modified Vebe time and air content tests of
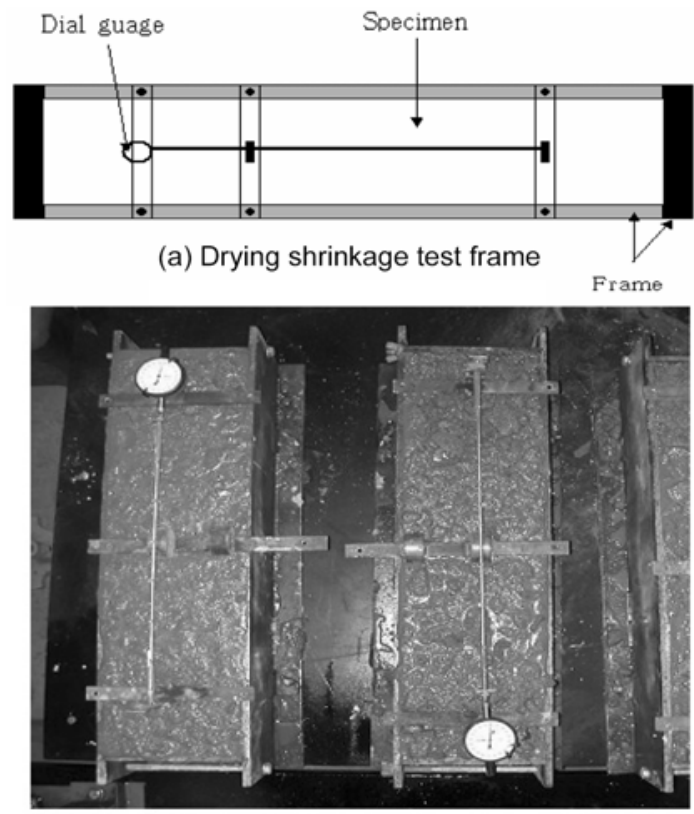

(b) Drying shrinkage test set-up

Fig. 3 Test frame and set-up of drying shrinkage test for RCC. the RCC mixture with varying amounts of fly ash replacement are shown in Figs. 4 and 5, respectively. In Fig. 4, the fly ash replacement did not influence the modified Vebe time. Also, as the fly ash replacement increased, the air content decreased, but this decrease was not significant (Fig.5).

\subsection{Compressive strength}

The compressive strengths for varying amounts of fly ash replacement are shown in Fig. 6. As expected, the compressive strength increased with age. The rate of increase depended on the level of cement replacement. In general, the concrete strength decreased with increasing fly ash at early ages. At 7 days, the compressive strength of the RCC mixture without fly ash was greater than that of concrete with fly ash, but as the age increased, the compressive strength of the RCC mixture with fly ash became greater than that of the RCC mixture without fly ash. Therefore, the RCC mixture using fly ash was more effective than the RCC mixture without fly ash in terms of long-term compressive strength. The best result was obtained with a $30 \%$ fly ash replacement, but this was not significantly better than the other results.

\subsection{Splitting tensile strength}

Splitting tensile tests are easier to perform and can provide more consistent results than direct tensile tests. However, splitting tensile test results tend to over predict the actual tensile strength and should be adjusted by a strength reduction factor of 0.75 to reflect the results that would be obtained from direct tensile tests. The splitting tensile strengths for varying amounts of fly ash replacement are shown in Fig. 7. In Fig. 7, the splitting tensile strength of the RCC mixture increased up to $30 \%$ fly ash replacement, but then decreased. The splitting tensile strength of

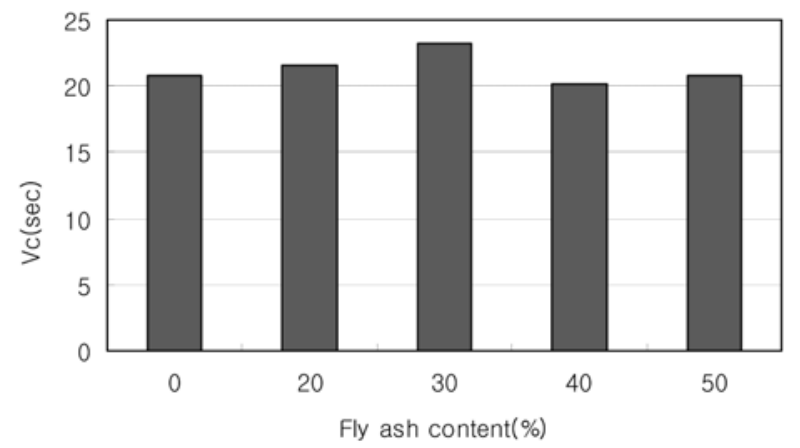

Fig. 4 Modified Vebe time with fly ash replacement ratio.

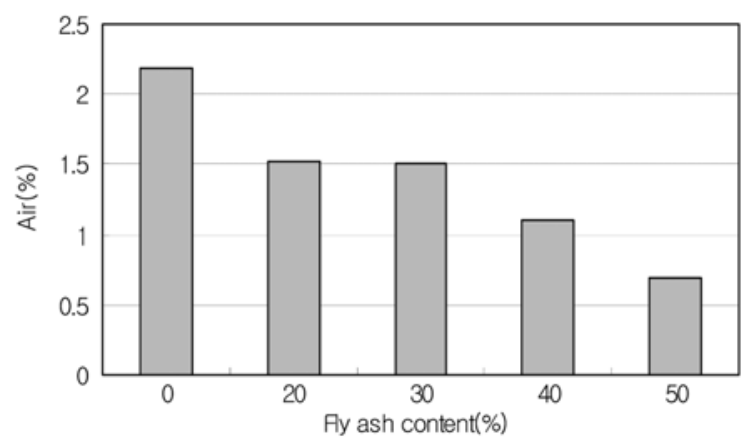

Fig. 5 Air content with fly ash replacement ratio. 


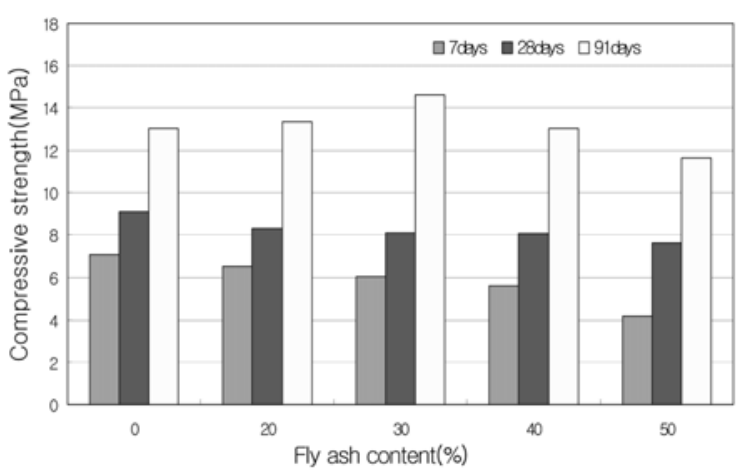

Fig. 6 Compressive strength with fly ash replacement ratio.

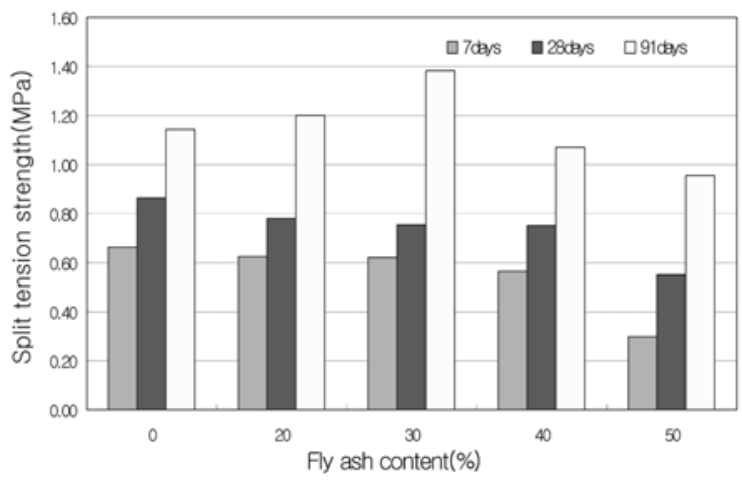

Fig. 7 Split tensile strength with fly ash replacement ratio.

the RCC mixtures was $12 \%$ to $15 \%$ of their compressive strength.

\subsection{Shear strength}

The shear strengths of RCC mixtures with varying amounts of fly ash replacement are shown in Fig. 8. The mixtures exhibited characteristics that were similar to the results of the tests of compressive and tensile strengths. Substitution with fly ash improved shear strength. The increase in shear strength was more significant for the mixture in which there was 30\% fly ash replacement, but the long-term shear strength of the RCC mixture with $50 \%$ fly ash replacement was less than that of the other RCC mixtures. The shear strength of the RCC mixtures was 10 to $13 \%$ of their compressive strengths.

\subsection{Chloride ion permeability}

The results of the chloride ion permeability tests of RCC mixed with fly ash replacement are shown in Fig. 9. The mixture

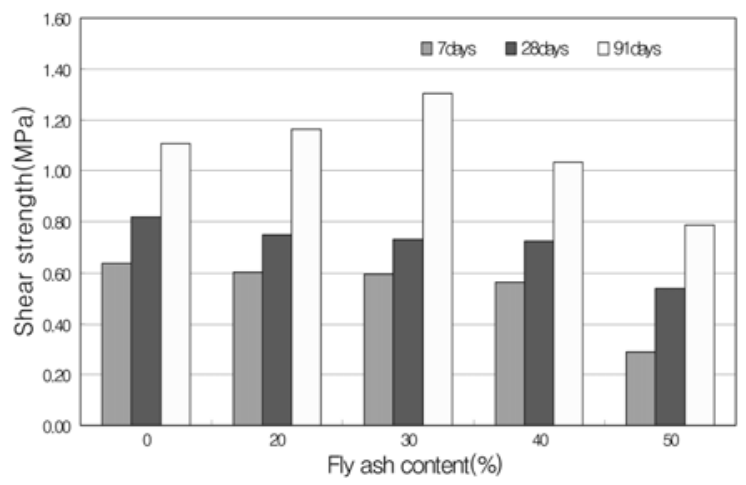

Fig. 8 Shear strength with fly ash replacement ratio without fly ash showed the lowest permeability initially, but the permeability of the mixture with fly ash gradually decreased, and was lowest after 91 days of curing. This is because fly ash is a pozzolan material that increases the long-term strength of the RCC mixture, thereby increasing the watertightness of the mixture.

\subsection{Abrasion}

The abrasion resistance test results are shown in Fig. 10. The RCC mixture had a relatively low abrasion resistance initially, but subsequently the abrasion resistance increased. The highest abrasion resistance was recorded after curing for 91 days. The RCC mixture with $30 \%$ fly ash replacement had a higher abrasion resistance than the other mixtures.

\subsection{Drying shrinkage}

The characteristics of drying shrinkage are shown in Fig. 11. The RCC mixture using fly ash had better drying shrinkage

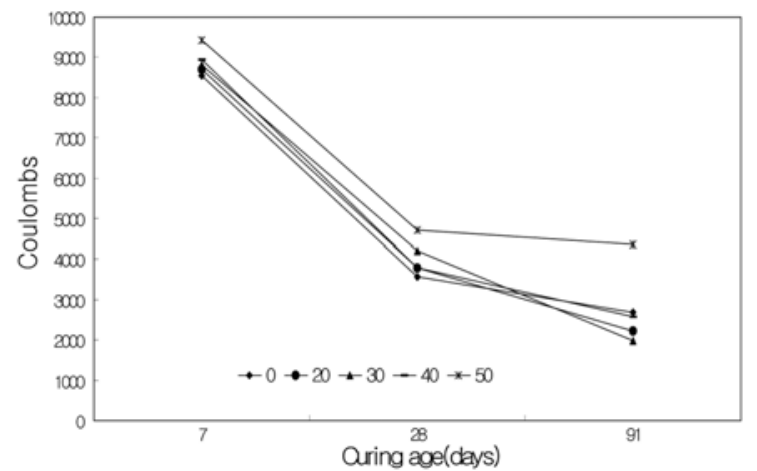

Fig. 9 Chloride ion permeability with fly ash replacement ratio.

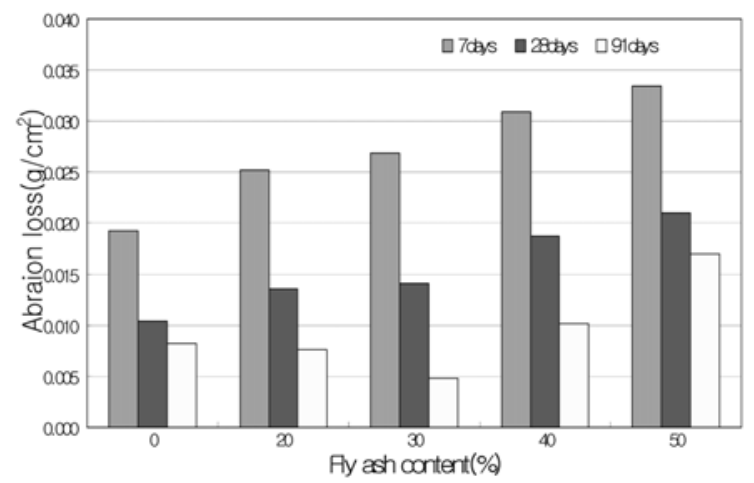

Fig. 10 Abrasion resistance with fly ash replacement ratio.

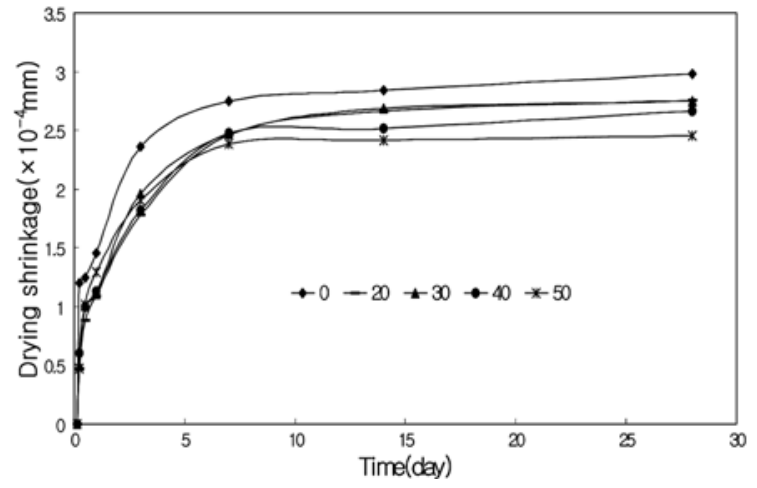

Fig. 11 Drying shrinkage with fly ash replacement ratio. 
control properties than did the RCC mixture without fly ash. Also, as the fly ash replacement increased, the drying shrinkage decreased. In particular, the drying shrinkage of the RCC mixture with $30 \%$ fly ash replacement was less than that of the RCC mixture without fly ash.

\section{Conclusions}

The influence of different proportions of fly ash on the behavior of RCC was investigated. Based on the results presented in this paper, the following conclusions can be drawn.

1) The fly ash replacement by cement weight did not affect the modified Vebe time and air content of the RCC.

2) The compressive, tensile, and shear strengths of the RCC mixture without fly ash were greater than those of the RCC mixtures with fly ash initially, but the mixtures with fly ash were more effective than those without fly ash in terms of longterm strength. The best results were obtained with $30 \%$ fly ash replacement.

3) As the amount of fly ash replacement increased, the drying shrinkage decreased. Also, the drying shrinkage of the RCC mixture with a $30 \%$ fly ash replacement was less than that of the RCC mixture without fly ash.

4) The mixture without fly ash initially showed the lowest permeability, but the permeability of the mixtures with fly ash gradually decreased was lowest after 91days.

5) Initially, the RCC mixtures had relatively low abrasion resistance, but as their ages increased, their abrasion resistance increased. The RCC mixture with $30 \%$ fly ash replacement was more effective than the other mixtures.

6) Based on the results of this study, a $30 \%$ fly ash replacement is optimum for RCC production for dam applications.

\section{References}

1. American Concrete Institute Committee 207, "Roller Compacted Mass Concrete," ACI 207.5R-89, Detroit, Michigan, 1988, pp.1 15.

2. Choi, Y., Neighbors, J. D., and Reichler, J. D., "Cold Weather Placement of RCC," Journal of Materials in Civil Engineering, April 2003, pp.118 124.
3. Dunstan, M. R. H., "Rolled Concrete for Dams-Construction Trials Using High Fly ash Content Concrete," Technical Note 106, CIRIA (Construction Industry Research and Information Association), SW1P 3AU, UK, 1981, pp.1 24.

4. Reed, P. A., Neeley, B. D., Green, M. L., and Amundson, C. T., Roller Compacted Concrete (RCC) Dams; Report 1, Laboratory Characterization of RCC Cores from Elk Creek Dam, Trail Oregon, Department of the army US Army Corps of Engineers Washington, DC, USA, 1998, pp.1 8.

5. Hall, D. J. and Houghton, D. L., Roller Compacted Concrete Studies at Lost Creek Dam, US Army Engineer District, Portland, USA, 1974, pp.3 9.

6. Hansen, K. D. and Reinhard, W. G, Roller-Compacted Concrete, McGraw-Hill, Inc., 1991, 12 45.

7. Hirose, T. and Yanagida, T., "Burst of Growth Demands Speed Economy," Concrete International, Vol.6, No.5, 1984, pp.14 18.

8. Japan Cement Association, RCD Construction Method Committee, Report on Construction Example of RCD Dams, 1996, pp.3 11.

9. Logle, C. V., "Economic Considerations in Selection of a Roller Compacted Concrete Dam," Proceedings of the Symposium sponsored by the Colorado Section and Construction Division of the American Society of Civil Engineers in conjunction with the ASCE Convention in Denver, Colorado 1985, pp.111 122.

10. Nagataki, S., Yangida, T., and Okumur, T., "Construction of Recent RCD-concrete Dam Projects in Japan," Proceedings of the Symposium sponsored by the Colorado Section and Construction Division of the American Society of Civil Engineers in Conjunction with the ASCE Convention in Denver, Colorado, 1985, pp.62 70.

11. Tazawa, E., Autogenous Shrinkage of Concrete, E F\&N SPON, 1999, pp.34 60.

12. Tynes, W. O., Feasibility Study of No-slump Concrete for Mass Concrete Construction, US Army Engineer Waterways Experiment Station-Miscellaneous Paper C-73-10, October 1973.

13. US Army Corps of Engineers, EM 1110-2-2006-RollerCompacted Concrete, Department of the army, US Army Corps of Engineers, Washington DC, USA, 2000, pp.21 35.

14. US Army Corps of Engineers, Walla Walla District, Willow Creek Dam Concrete Report, 2001, pp.5 30. 